Creative Commons User License: CC BY-NC-ND

Abstracted by: EBSCOhost, Electronic Journals Service (EJS), Google Scholar, Journal Seek, Scientific Commons,

Food and Agricultural Organization (FAO), CABI and Scopus
Journal of Agricultural Extension

Vol. 24 (2) April, 2020

ISSN(e): 24086851; ISSN(Print); 1119944X

http://journal.aesonnigeria.org

http://www.ajol.info/index.php/iae

Email: editorinchief@aesonnigeria.org

http://eoi.citefactor.org/10.11226/v24i2

\title{
Adoption of Improved Maize Production Technologies in Punjab Province, Pakistan \\ https://dx.doi.org/10.4314/jae.v24i2.1
}

\section{Muddassir, Muhammad}

Department of Agricultural Extension and Rural Society, King Saud University, Riyadh, Kingdom of Saudi Arabia

Email: ranamuddassir@gmail.com

+966594728018

\section{Al Shenaifi, Mohamed Saleh}

Department of Agricultural Extension and Rural Society, King Saud University, Riyadh, Kingdom of Saudi Arabia

Email: shenaifi@ksu.edu.sa

+966505493006

\section{Kassem, Hazem Salah}

Department of Agricultural Extension and Rural Society, King Saud University, Riyadh, Kingdom of Saudi Arabia

Email: hskassem@ksu.edu.sa

$$
\text { +966581045671 }
$$

\section{Alotaibi, Bader Alhafi}

Department of Agricultural Extension and Rural Society, King Saud University, Riyadh, Kingdom of Saudi Arabia

Email: balhafi@ksu.edu.sa

$$
+966504240201
$$

\section{Abstract}

The study assessed farmers' awareness and adoption of maize production technologies in Punjab Province, Pakistan. A simple random sampling technique was used to collect data from 120 farmers in the study area through personal interview using a structured interview schedule. The study found that $48.3 \%$ of the respondents had obtained information about agricultural practices from extension agents and that $65 \%$ of the respondents regularly visited the agricultural extension department. Furthermore, 62.5\% of the respondents had a high awareness about improved maize cultivation practices and 53\% had already adopted the techniques. Farmers who visited the agricultural extension department had a higher awareness and were more likely to adopt improved maize cultivation practices compared with farmers who did not visit the agricultural extension department. Farmers' education level, cultivated area, and whether they visited the extension department were the key determinants of adoption of new technologies. Government policies in the province should aim to improve methods of extension delivery for the implementation of effective farming practices in small-scale farming systems. 
Creative Commons User License: CC BY-NC-ND

Abstracted by: EBSCOhost, Electronic Journals Service (EJS), Google Scholar, Journal Seek, Scientific Commons,

Food and Agricultural Organization (FAO), CABI and Scopus

http://eoi.citefactor.org/10.11226/v24i2
Journal of Agricultural Extension

Vol. 24 (2) April, 2020

ISSN(e): 24086851; ISSN(Print); 1119944X

http://journal.aesonnigeria.org

http://www.ajol.info/index.php/iae

Email: editorinchief@aesonnigeria.org

Governments should also formulate recommendations, which are easily understandable by illiterate or poorly-educated farmers and should support the formation of groups to facilitate information transfer.

Key words: Awareness, adoption, farmers, agricultural extension, maize, Pakistan.

\section{Introduction}

Agriculture is the major source of foreign exchange earnings in Pakistan and is a key economic sector, also providing raw materials to the main industrial regions of the country. Agriculture accounts for $19.8 \%$ of the country's gross domestic product (GDP) and employs the largest proportion of the country's total labour force by a large margin (Government of Pakistan, 2016). Maize plays an important role in the economic development of Pakistan. Maize (Zea mays $\mathrm{L}$ ) is the third-most important crop after wheat and rice and its production contributed to approximately $0.4 \%$ of the GDP and $2.1 \%$ of the total profits of country-wide agriculture (Shah et al., 2014). The average productivity in maize cultivation is $2,850 \mathrm{~kg} / \mathrm{ha}$, the highest among all cereals grown in the country in 2014 . The bulk (99\%) of total maize production primarily comes from two provinces: North-West Frontier Province (NWFP) and Punjab (Rehman et al., 2015).

The effective communication of agricultural techniques is one of the most important processes in agricultural development (Aziz et al., 2015). Novel agricultural technologies provide a potential means for farmers to increase their yields and, subsequently, their overall income and standards of living (Mudombi, 2013). Creating awareness and encouraging the adoption of novel agricultural practices among farmers and stimulating their interest are basic essentials for accelerating the nationwide implementation of new agricultural techniques. The increasing rate of adoption of innovations is affected by number of factors include socioeconomic characteristics and economic, technological, and institutional factors (Mwangi \& Kariuki, 2015). Agricultural extension in Pakistan contributes to increases in agricultural productivity by educating growers about improved agricultural practices: proper seed requirements, timely sowing, the balanced and efficient use of fertilizer, the efficient use of irrigation methods, pesticide use, effective crop management, harvesting, threshing, storage, and marketing by the implementation of training sessions and different individual, group, and mass extension methods (Shahbaz \& Ata, 2014).

According to Pakistan Business Council (2018), the potential agricultural productivity is far lower than the highest average production values of other countries with $35 \%-52 \%$ for crops such as maize, cotton, wheat, and sugarcane. The low national crop yield reflects the technological gaps that exist in maize production among farmers. Limited systematic efforts have been made to assess the underlying causes behind the low productivity of maize in Pakistan. On the basis of this background, the current study aimed to understand farmers' awareness concerning novel agricultural practices and their attitude towards the adoption of recommended practices in Pakistan. The specific objectives of the study were to assess awareness 
Creative Commons User License: CC BY-NC-ND

Abstracted by: EBSCOhost, Electronic Journals Service (EJS), Google Scholar, Journal Seek, Scientific Commons,

Food and Agricultural Organization (FAO), CABI and Scopus

http://eoi.citefactor.org/10.11226/v24i2
Journal of Agricultural Extension

Vol. 24 (2) April, 2020

ISSN(e): 24086851; ISSN(Print); 1119944X

http://journal.aesonnigeria.org

http://www.ajol.info/index.php/iae

Email: editorinchief@aesonnigeria.org

and adoption of maize farmers concerning novel agricultural technologies and to determine which factors influenced farmers' decisions to either adopt or not adopt novel practices.

\section{Methodology}

Quantitative research was conducted in the Jhang District, Punjab $\left(31.1471^{\circ} \mathrm{N}\right.$, $\left.75.3412^{\circ} \mathrm{E}\right)$. In 1998 , according to a Pakistan census, the population of the district was 2.8 million, of which only $23 \%$ lived in urban areas. The district covers an area of $8,809 \mathrm{~km}^{2}$, and almost all of the land in the Jhang District is rocky in nature. Tehsil Jhang is a subdivision (Tehsil) of the Jhang District. Tehsil Jhang consists of 55 Union Councils (UCs). Fifteen unions are urban and 40 are rural. Six rural union councils were randomly selected to represent the population of maize farmers in the study area. Each union council contained approximately 6 villages, and one village was randomly selected from each UC. The villages included in the survey were; Bagh Wala, Rodu Sultan, Khewa, Peer Kot Sadhana, Ballo Shahabal, and Pakkay Wala. The combined populations of the six villages included around 1200 farmers (Agricultural Directorate of Punjab, 2017). A subset of 120 farmers $(10 \%$ of all farmers in the region) were randomly selected to participate in the survey.

An interview schedule was developed, tested, and validated. Questions were presented in the appropriate local languages for the convenience of interviewees to ensure accurate answers to the survey questions. The validity and reliability of the interview schedule was tested on 20 respondents prior to the survey. Preliminary testing identified necessary amendments to the survey which were made prior to the survey period. The reliability of the attitude scale was tested using Cronbach's Alpha test $(\alpha=0.81)$. The index of improved maize technologies consisted of 26 practices classified into 10 categories: land preparation, sowing, seeds, irrigation, intercultural practices, chemical fertilizers, plant protection measures, diseases, weedicides, and harvesting methods. Technologies listed in the survey were selected from the latest extension pamphlets provided to maize farmers in Pakistan.

Variables including farmers' age, education level, area of owned land, area of land cultivated, and farming experience, were used as independent variables. The awareness and adoption of agricultural technologies by the respondents were used as dependent variables. The measurement scale of awareness was (high and low), while the measurement scale used for adoption was (adopters and non-adopters). The data were analysed using Statistical Product and Service Solution (SPSS) ver.22. Frequencies, percentages, and arithmetic mean were used to describe data and presenting the results. Moreover, a binary logit regression model was used to determine the factors influencing the farmers' technological awareness and adoption. The list of explanatory variables used in the model are presented in Table 1. 
Creative Commons User License: CC BY-NC-ND

Abstracted by: EBSCOhost, Electronic Journals Service (EJS), Google Scholar, Journal Seek, Scientific Commons,

Food and Agricultural Organization (FAO), CABI and Scopus
Journal of Agricultural Extension

Vol. 24 (2) April, 2020

ISSN(e): 24086851; ISSN(Print); 1119944X

http://journal.aesonnigeria.org

http://www.ajol.info/index.php/iae

Email: editorinchief@aesonnigeria.org

Table 1. Definition of variables included in the awareness and adoption models.

\begin{tabular}{|c|c|c|}
\hline Variables & Description & Measurement \\
\hline \multicolumn{3}{|l|}{ Dependent variables } \\
\hline Adoption & Adoption of maize cultivation practices & $1=$ adoption, $0=$ non-adoption \\
\hline Awareness & $\begin{array}{c}\text { Awareness of maize cultivation } \\
\text { practices }\end{array}$ & $\begin{array}{c}1=\text { high awareness, } 0=\text { low or no } \\
\text { awareness }\end{array}$ \\
\hline \multicolumn{3}{|l|}{ Explanatory variables } \\
\hline Age & Age of respondent & Age of the farmer in years \\
\hline Education & Level of education (dummy) & $\begin{array}{c}1=\text { secondary school education or } \\
\text { above, } 0=\text { other }\end{array}$ \\
\hline Farming experience & Farming experience of respondent & Years of farming experience \\
\hline Cultivated area & Area of land used in cultivation & Area cultivated in acres * \\
\hline Land area & $\begin{array}{c}\text { Size of farm (owned, rented, or } \\
\text { shared) }\end{array}$ & Area owned in acres * \\
\hline Interaction with extension agents & $\begin{array}{l}\text { Frequency of farmers' visits to/by } \\
\text { extension agents }\end{array}$ & $\begin{array}{c}\% \text { of respondents who responded } \\
\text { with (yes) }\end{array}$ \\
\hline
\end{tabular}

* 1 Acre $=4046 \mathrm{~m}^{2}$ (0.4 hectares).

\section{Results and Discussion}

\section{Extension Contacts}

Figure 2 shows data on the respondents' participation in agricultural extension programmes. Around half $(48.3 \%)$ of the respondents had received information concerning maize cultivation practices from extension agents, while $31.7 \%$ of the respondents obtained information from progressive farmers. This means that a large proportion of the farmers still acquires knowledge from informal resources. The success of extension services depends on the ability of extension agents to transfer technological information and recommendations to farmers. In this context, the study found that extension agents visited farmers fortnightly (93.3\%) (Figure 3). 
Creative Commons User License: CC BY-NC-ND

Abstracted by: EBSCOhost, Electronic Journals Service (EJS), Google Scholar, Journal Seek, Scientific Commons,

Food and Agricultural Organization (FAO), CABI and Scopus

http://eoi.citefactor.org/10.11226/v24i2
Journal of Agricultural Extension

Vol. 24 (2) April, 2020

ISSN(e): 24086851; ISSN(Print); 1119944X

http://journal.aesonnigeria.org

http://www.ajol.info/index.php/iae

Email: editorinchief@aesonnigeria.org

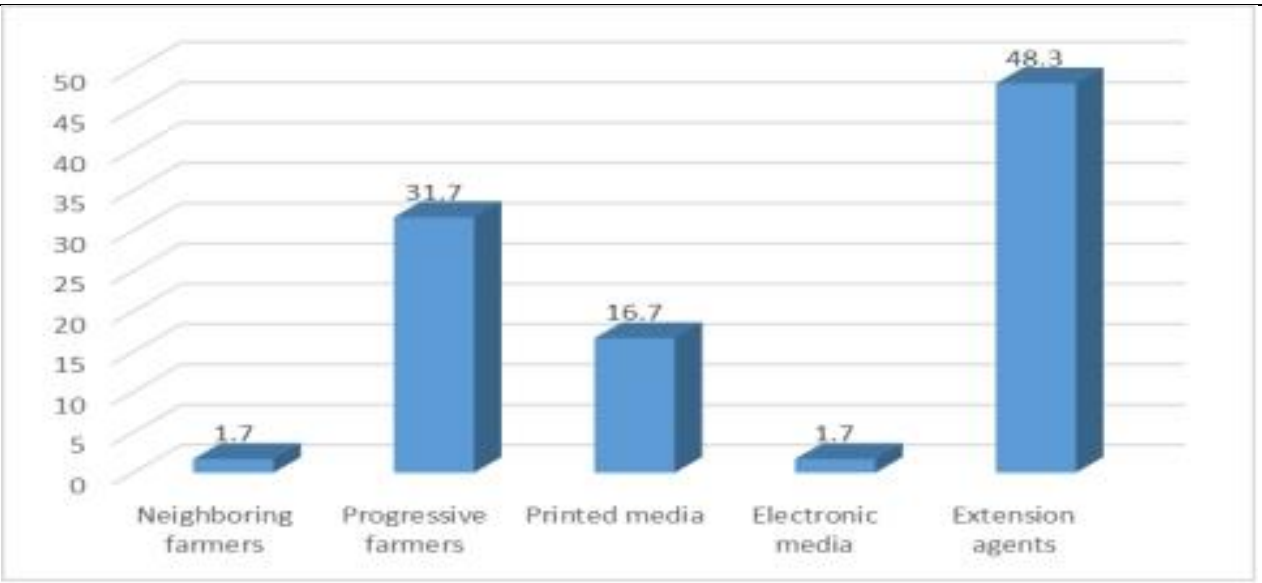

Figure 2: Sources of information on agricultural practices.

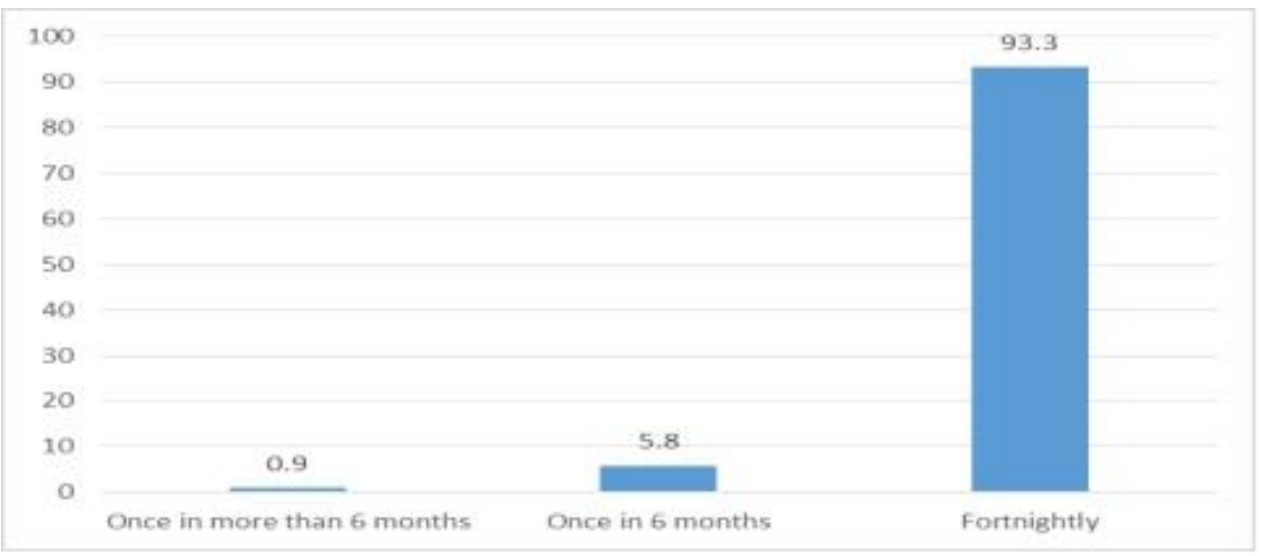

Figure 3: Extension agents' visiting frequencies.

As shown in Figure 4, 65\% of the respondents visited agricultural extension departments. The frequent use of agricultural extension departments by local farmers may be a significant and positive influence on the technological awareness and adoption of maize cultivation practices. 


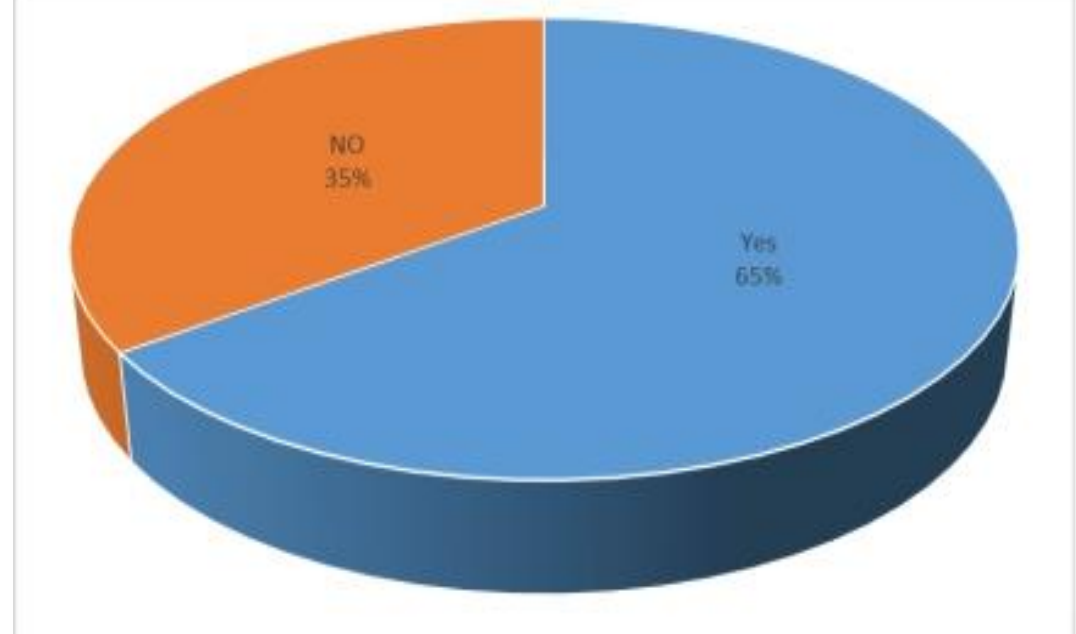

Figure 4: Number of respondents who frequently visited the extension department.

Extension agencies play a key role in promoting the adoption of agricultural technologies and changing the knowledge, attitudes, and skills of local farmers (AlZahrani et al., 2016). Moreover, agricultural extension aids in the spreading of awareness and the sharing of knowledge among different partners in the agricultural sector (Ngaka \& Zwane, 2017). In the present study, the frequency of farmers' contact with extension services was similar to that reported by another study conducted by Shah, Asmuni, and Ismail (2013) in Malaysia. The same study also found that the majority of the respondents contacted extension services fortnightly. Visiting extension services facilitates the transfer and exchange of information that can be converted into functional knowledge, which in turn promotes crop productivity (Baiyegunhi, Majokweni, and Ferrer, 2019; Baloch \& Thapa, 2018).

\section{Awareness and Adoption of Improved Maize Cultivation Practices}

Figure 5 shows the percentage of respondents who were highly aware of the listed improved maize cultivation practices and the percentage who had adopted the practices at the time of the survey. A total of $46.4 \%$ of the respondents were aware of land preparation practices, but only $41.6 \%$ of the respondents had adopted. More than half $(54.4 \%)$ of the respondents were aware of sowing practices, but only $49.1 \%$ had adopted. More also, many (79.2\%) of the respondents had adopted seed-based practices, with $91.9 \%$ of the respondents aware. Considering irrigation practices, $76 \%$ were aware of irrigation techniques, while $73.7 \%$ adopted. Approximately $57 \%$ of the respondents reported that they were aware of inter-cultural practices, but only $54.5 \%$ had adopted. Regarding chemical fertilizers, $77.9 \%$ of the respondents were aware of the use, while only $72.2 \%$ adopted. The overwhelming of the respondents $(95 \%)$ were highly aware about pest control, and $90 \%$ of them adopted these practices. In the same vein, the vast the majority of the respondents $(93.3 \%)$ were highly aware about disease control, but $81.3 \%$ of them adopted these practices. 
Creative Commons User License: CC BY-NC-ND

Abstracted by: EBSCOhost, Electronic Journals Service (EJS), Google Scholar, Journal Seek, Scientific Commons,

Food and Agricultural Organization (FAO), CABI and Scopus

http://eoi.citefactor.org/10.11226/v24i2
Journal of Agricultural Extension

Vol. 24 (2) April, 2020

ISSN(e): 24086851; ISSN(Print); 1119944X

http://journal.aesonnigeria.org

http://www.ajol.info/index.php/iae

Email: editorinchief@aesonnigeria.org

Furthermore, $98.8 \%$ of the respondents were highly aware about weed control practices, but $91.3 \%$ adopted these practices. All farmers (100\%) were aware of harvesting practices, but only $82.1 \%$ of the respondents had adopted.

The results demonstrate variability in farmers' awareness and adoption of improved maize cultivation practices. The results are consistent with those of Mango et al. (2017), who found that the awareness and adoption of water and conservation practices in South Africa varied between specific practices and that adopters could be classified into early adopters and laggards depending on the time of their adoption. Accordingly, agricultural extension agents could benefit from farmers experienced in a variety of agricultural practices to facilitate farmer-to-farmer learning, mobilization of knowledge, and the formation of effective information networks (Susaeta et al., 2018).

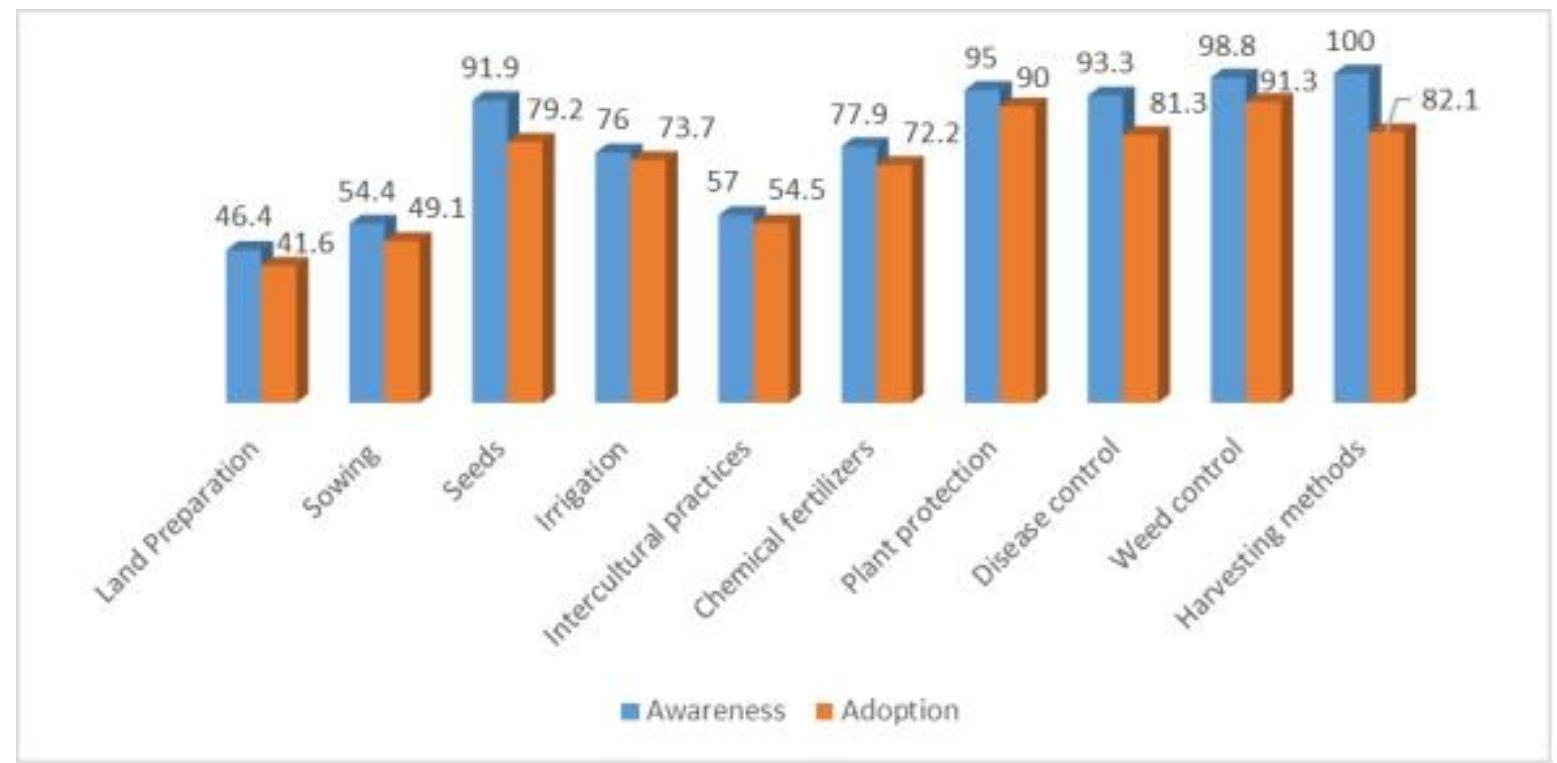

Figure 5: Awareness and adoption of maize cultivation practices.

\section{Factors Influencing Farmer Awareness and Adoption}

Table 4 shows the results of logistic regression analyses using the factors affecting the awareness and the adoption of improved maize cultivation practices by local farmers. Personal attributes (i.e. age, education, land area, cultivated area, farming experience) and whether farmers visited the agricultural extension department were hypothesized to influence their awareness and adoption behaviours. Three out of the six variables used in the adoption model were statistically significant at $p<0.05$ and $p<0.01$ levels, while no significant variables were found in the awareness model. This result could partly be explained by the high overall awareness of farmers (Figure 5). The observed chi-squared value of 74.8 indicates that the likelihood ratio statistics are highly significant $(P<0.01)$ and that the adoption model has a strong 
Creative Commons User License: CC BY-NC-ND

Abstracted by: EBSCOhost, Electronic Journals Service (EJS), Google Scholar, Journal Seek, Scientific Commons,

Food and Agricultural Organization (FAO), CABI and Scopus
Journal of Agricultural Extension

Vol. 24 (2) April, 2020

ISSN(e): 24086851; ISSN(Print); 1119944X

http://journal.aesonnigeria.org

http://www.ajol.info/index.php/iae

Email: editorinchief@aesonnigeria.org

http://eoi.citefactor.org/10.11226/v24i2

explanatory power. The Nagerkeke $R^{2}$ value was 0.38 , indicating that the explanatory variables explained approximately $38 \%$ of the variation in farmers' adoption habits.

The educational status of the respondents significantly influenced the likelihood that they adopted improved maize cultivation practices. Specifically, a one-year increase in formal education is associated with a $19 \%$ increase in the chance a farmer will adopt recommended maize cultivation practices. The results also show that a 4-acre increase in cultivated area size increases the odds of adoption of improved maize cultivation practices by $42 \%$. In addition, whether farmers had visited the extension department was also a significant determinant of adoption. The likelihood of practice adoption was found to be $2.11 \%$ greater for farmers who had visited the extension department. This result implies that extension recommendations play an essential role in modernizing agricultural practices. The level of education of the farmers was one of the socio-economic attributes that significantly influenced farmers' adoption of agricultural practices. A probable reason for this is that educated farmers are more willing to seek new information and are more capable in processing and evaluating its impact on crop productivity. The results are consistent with those of previous studies (Danso-Abbeam et al., 2017; Kadafur et al., 2017; Mmbando \& Baiyegunhi, 2016; Salifu \& Salifu, 2015).

Another personal attribute that was associated with the adoption of agricultural practices by farmers was the area under cultivation. Larger size of farm was associated with farmers being more likely to adopt the maize technologies, in comparison to the group of farmers with a smaller farm size. This could be because farming in larger pieces of land encourage farmers to accept the risks and test the new practices and technologies. Moreover, farmers who cultivate larger areas can better take advantage of market opportunities and can thus increase their income to a greater extent. These findings are similar to those of previous studies (DansoAbbeam et al., 2017; Fadare Fadare, Akerele, and Toritseju, 2014, Issa, Kagbu, and Abdulkadir, 2016; Kadafur et al., 2017). The study found that access to extension services was a significant determinant of adoption of recommended practices. Farmers may have the ability to observe the positive effects of recommended practices by comparing them with traditional practices. According to Gebrehiwot (2017), the reason behind the low adoption of novel cultivation practices was the lack of contact of farmers with extension agents. The association between farmers and extension service use could facilitate the identification of the real needs of farmers (Shah, Asmuni, and Ismail, 2013). This finding is supported by the results of previous studies (Ademiluyi, 2014; Danso-Abbeam et al.,2017; Fadare, Akerele, and Toritseju, 2014; Kadafur et al., 2017). 
Creative Commons User License: CC BY-NC-ND

Abstracted by: EBSCOhost, Electronic Journals Service (EJS), Google Scholar, Journal Seek, Scientific Commons,

Food and Agricultural Organization (FAO), CABI and Scopus

http://eoi.citefactor.org/10.11226/v24i2
Journal of Agricultural Extension

Vol. 24 (2) April, 2020

ISSN(e): 24086851; ISSN(Print); 1119944X

http://journal.aesonnigeria.org

http://www.ajol.info/index.php/iae

Email: editorinchief@aesonnigeria.org

Table 4: Factors influencing farmers' awareness and adoption.

\begin{tabular}{|c|c|c|c|c|c|c|}
\hline \multirow{2}{*}{$\begin{array}{l}\text { Explanatory } \\
\text { variables }\end{array}$} & \multicolumn{3}{|c|}{ Awareness Model } & \multicolumn{3}{|c|}{ Adoption Model } \\
\hline & Odds & S.E. & Wald & Odds & S.E. & Wald \\
\hline \multirow{2}{*}{$\begin{array}{l}\text { Age } \\
\text { Education }\end{array}$} & -1.85 & 1.66 & 1.89 & 1.54 & 0.99 & 2.32 \\
\hline & 1.35 & 1.44 & 1.57 & 1.19 & 0.91 & $9.59^{*}$ \\
\hline Land area (acres) & -1.25 & 0.89 & 1.31 & -1.73 & 1.68 & 2.42 \\
\hline $\begin{array}{l}\text { Cultivated area } \\
\text { Farming }\end{array}$ & -1.78 & 1.48 & 1.39 & 4.42 & 1.48 & $10.55^{*}$ \\
\hline experience & -1.85 & 1.66 & 1.95 & 1.29 & 1.4 & 1.45 \\
\hline \multirow[t]{2}{*}{$\begin{array}{l}\text { Visiting extension } \\
\text { agent (\% yes) }\end{array}$} & 1.18 & 1.42 & 0.000 & 2.11 & 0.95 & $5.26^{*}$ \\
\hline & $\begin{array}{l}2 \log \\
\text { chi-squ } \\
\text { (chi-so } \\
\text { Nager }\end{array}$ & \multicolumn{2}{|c|}{$\begin{array}{lr}\text { likelihood }= & 54.8, \\
\text { are }=8.8, & \text { probability } \\
\text { lare })=0.22, & = \\
\text { eke } R^{2}=0.09 & \end{array}$} & \multicolumn{3}{|c|}{$\begin{array}{lrr}\text { likelihood }= & 233.1, \\
\text { uare }=74.8, & \text { probability } \\
\text { quare }) \quad & 0.00, \\
\text { keke } R^{2}=0.38 & \end{array}$} \\
\hline
\end{tabular}

${ }^{*} P \leq 0.05,{ }^{* *} P \leq 0.01$

\section{Conclusion and Recommendations}

Education, cultivated area, and visit extension services influenced farmers' adoption of agricultural practices. Extension plays a key role in the adoption of agricultural practices by maize farmers, and more attention should be paid to the development of better methods of information delivery. Furthermore, the results suggest that any extension programme providing information concerning maize cultivation in the study area should recognize the heterogeneity in farmers' personal attributes and farmspecific characteristics. On the basis of the empirical findings, the study recommends that the contact between farmers and extension agents should be strengthened, facilitating the training of progressive farmers on new cultivation practices. It is also necessary to improve the frequency and availability of contact between extension agents and farmers. This can be achieved via the implementation of more innovative ways of communication (e.g., information and communication technology (ICT), FM radio, television, and agricultural journalism) in the region.

\section{References}

Ademiluyi, I. O. (2014). Adoption of improved maize varieties among farmers in Bassa local government area of Plateau State, Nigeria. International Journal of Innovative Agriculture and Biology Research, 2(4), 26-33.

Agricultural Directorate of Punjab (2017). Punjab information technology board, Punjab, Pakistan. https://www.pitb.gov.pk 
Creative Commons User License: CC BY-NC-ND

Abstracted by: EBSCOhost, Electronic Journals Service (EJS), Google Scholar, Journal Seek, Scientific Commons,

Food and Agricultural Organization (FAO), CABI and Scopus

http://eoi.citefactor.org/10.11226/v24i2
Journal of Agricultural Extension

Vol. 24 (2) April, 2020

ISSN(e): 24086851; ISSN(Print); 1119944X

http://journal.aesonnigeria.org

http://www.ajol.info/index.php/iae

Email: editorinchief@aesonnigeria.org

Al-Zahrani, K. H., Aldosari, F. O., Baig, M. B., Shalaby, M. Y., and Straquadine, G. (2016). Role of agricultural extension service in creating decision-making environment for the farmers to realize sustainable agriculture in Al-Qassim and Al-kharj-Saudi Arabia. The Journal of Animal and Plant Sciences, 26(4), 1063-1071.

Aziz, R., Siddiqui, B. N., Ali, A., Ali, J., and Raza, Q. (2015). Farmer's perception regarding "Haryali" and "Kisan Time" programmes telecast by PTV. Academia Journal Agricultural Research, 3(11): 308-311.

Baiyegunhi, L. J. S., Majokweni, Z. P., \& Ferrer, S. R. D. (2019). Impact of outsourced agricultural extension program on smallholder farmers' net farm income in Msinga, KwaZulu-Natal, South Africa. Technology in Society, 57, 1-7.

Baloch, M.A., \& Thapa, G.B. (2018). The effect of agricultural extension services: Date farmers' case in Balochistan, Pakistan. Journal of the Saudi Society of Agricultural Sciences, 17(3), 282-289.

Danso-Abbeam, G., Bosiako, J. A., Ehiakpor, D. S., and Mabe, F. N. (2017). Adoption of improved maize variety among farm households in the northern region of Ghana. Cogent Economics \& Finance, 5(1), 1-14.

Fadare, O. A., Akerele, D., \& Toritseju, B. (2014). Factors influencing adoption decisions of maize farmers in Nigeria. International Journal of Food and Agricultural Economics, $2(3), 45-54$.

Government of Pakistan. (2016).Pakistan economic survey 2015-16. Ministry of Finance, Government of Pakistan.

Gebrehiwot, K.G. (2017). The impact of agricultural extension on farmers' technical efficiencies in Ethiopia: A stochastic production frontier approach. South African Journal of Economic and Management Sciences, 20(1), 1-8.

Issa, F. O., Kagbu, J. H., and Abdulkadir, S. A. (2016). Analysis of socio-economic factors influencing farmers' adoption of improved maize production practices in Ikara Local Government Area of Kaduna State, Nigeria. Agrosearch, 16(2), 15-24.

Kadafur, M. I., Idrisa, Y. L., Kamara, A. Y., and Oyinbo, O. (2017). Understanding the drivers of adoption intensity of improved maize varieties in Northern Guinea Savannah of Borno State, Nigeria. Albanian Journal of Agricultural Sciences, 16(2), 59-66.

Mango, N., Makate, C., Tamene, L., Mponela, P., and Ndengu, G. (2017). Awareness and adoption of land, soil and water conservation practices in the Chinyanja Triangle, Southern Africa. International Soil and Water Conservation Research, 5(2), 122-129.

Mmbando, F. E., and Baiyegunhi, L. J. (2016). Socio-economic and institutional factors influencing adoption of improved maize varieties in Hai District, Tanzania. Journal of Human Ecology, 53(1), 49-56. 
Creative Commons User License: CC BY-NC-ND

Abstracted by: EBSCOhost, Electronic Journals Service (EJS), Google Scholar, Journal Seek, Scientific Commons,

Food and Agricultural Organization (FAO), CABI and Scopus

http://eoi.citefactor.org/10.11226/v24i2
Journal of Agricultural Extension

Vol. 24 (2) April, 2020

ISSN(e): 24086851; ISSN(Print); 1119944X

http://journal.aesonnigeria.org

http://www.ajol.info/index.php/iae

Email: editorinchief@aesonnigeria.org

Mudombi, M. (2013). Adoption of agricultural innovations: The case of improved sweet potato in Wedza community of Zimbabwe. African Journal of Science Technology Innovation and Development, 5(6), 459-46.

Mwangi, M., and Kariuki, S. (2015). Factors determining the adoption of new agricultural technology by smallholder farmers in developing countries. Journal of Economics and Sustainable Development, 6(5), 208-216.

Ngaka, M. J., \& Zwane, E. M. (2017). The role of learning networks in agricultural extension service delivery: A survey in the nine provinces of South Africa. South African Journal of Agricultural Extension, 45(2), 26-37.

Pakistan Business Council. (2018). Sustainable macro-economic growth report. Pakistan Business Council, Dubai, United Arab Emirates.

Raza, M. H., Shahbaz, B., and Bell, M. A. (2017). Review based analysis of adoption gap and training needs of farmers in Pakistan. International Journal of Agricultural Extension, 4(3), 185-193.

Rehman, A., Jingdong, L., Shahzad, B., Chandio, A. A., Hussain, I., Nabi, G., and lqbal, M. S. (2015). Economic perspectives of major field crops of Pakistan: An empirical study. Pacific Science Review B: Humanities and Social Sciences, 1(3), 145-158.

Salifu, H., \& Salifu, K. (2015). Determinants of farmers adoption of improved maize varieties in the Wa Municipality. American International Journal of Contemporary Research $5(4), 27-35$.

Shah, H., Khan, M. A., Akmal, N., and Akhtar, W. (2014). Assessment of the maize situation, outlook and investment opportunities to ensure food security in Pakistan. MAIZE-CRP Project Report. Social Sciences Research Institute, NARC, Pakistan.

Shah, J. A., Asmuni, A., and Ismail, A. (2013). Roles of extension agents towards agricultural practice in Malaysia. International Journal on Advanced Science, Engineering and Information Technology, 3(1): 59-63.

Shahbaz, B., and Ata, S. (2014). Enabling agricultural policies for benefiting smallholders in dairy, citrus and mango industries of Pakistan - Project No. ADP/2010/091. Background Paper, (2014/1).

Susaeta, F.L., Maino, M., Lapierre, L., Oviedo, P., Riquelme, R., Villarroel, A. B., Quintrel, M., Hervé-Claude, L.P. and Cornejo, J. (2018). The adoption of good practices for pesticides and veterinary drugs use among peasant family farmers of Chile. Agronomy, 8(10), 219-232. 